\title{
Productivity and efficiency analysis using DEA: Evidence from financial companies Listed in Bursa Malaysia
}

\author{
Omar Sharif $^{a}$, Md Zobaer Hasan ${ }^{\mathrm{b}}$, Florentina Kurniasari ${ }^{\mathrm{c}}$, Atang Hermawan ${ }^{\mathrm{d}}$ and Ardi Gunardi ${ }^{\mathrm{d}}$
}

${ }^{a}$ Daffodil International University, Dhaka, Bangladesh

${ }^{b}$ Monash University Malaysia, Bandar Sunway, Malaysia

${ }^{c}$ Universitas Multimedia Nusantara, Tangerang, Indonesia

${ }^{d}$ Universitas Pasundan, Bandung, Indonesia

C H R O N I C L E

Article history:

Received: October 2, 2018

Received in revised format: November 15,2018

Accepted: November 22, 2018

Available online:

November 22, 2018

Keywords:

Bursa Malaysia

$D E A$

Efficiency

Financial Company

Malmquist productivity index

\section{A B S T R A C T}

\begin{abstract}
This study evaluates the technical efficiency, productivity change of financial companies listed in the Malaysian stock exchange (Bursa Malaysia) and examines the effects of productivity change on efficiency over the period 2007-2016. Moreover, this study also concentrates on the ranking of financial companies according to their efficiency scores. Data Envelopment Analysis (DEA) is utilized on a Malmquist Productivity Index in order to calculate the financial companies' efficiency scores. The results of this study show that some firms were fully efficient. The results implied that these companies were in optimal control of their inputs or resources to generate the maximum outputs. Also, the results indicate a tremendous productivity gain was mostly because of a positive shift in frontier technology and positive shift in technical efficiency. This study is significant because it helps to identify the efficient companies from the financial sector in Malaysia based on multiple inputs and outputs by using the DEA model. Common misspecification problems observed that instability of efficiency scores over productivity.
\end{abstract}

(C) 2019 by the authors; licensee Growing Science, Canada

\section{Introduction}

Bursa Malaysia, Malaysian capital market, has been increased very significantly especially after several financial crises (Ong \& Ng, 2018). Stable and developing financial market can attract investors (Ali et al., 2018a). It is well established in investors' mind that investing in the stock market will give them satisfactory return, and it will contribute a major improvement for economic development (Ali et al., 2018b; John, 2018). Many techniques have been applied by investors to optimize their return and minimize the risk of their investment (Rossi \& Gunardi, 2018; Rashid \& Mehmood, 2018; Azizan \& Sorooshian, 2014). By using non-parametric or parametric frontier techniques, a great deal of efforts have been devoted on the financial system in attaining the overall economic performance with changes within the regulatory environment. Additionally, the globalization of financial markets to research the efficiency of financial firms has been created by using different techniques (Vardar, 2013). Moreover, the efficiency of the financial company is more important for financial growth. In current years, the

* Corresponding author.

E-mail address: omar.sharif.ged@diu.edu.bd (O. Sharif)

(C) 2019 by the authors; licensee Growing Science, Canada doi: $10.5267 /$ j.msl.2018.11.010 
academic research on the performance of financial institutions has increasingly focused on frontier efficiency. In case of corporate process progress performance evaluation and benchmarking are extensively practiced methods (Becsky-Nagy \& Fazekas, 2014). If there is no standard available for the evaluation then benchmarking can be notably imperative for the evaluation (Orbán, 2013). For performance evaluation, ample change has occurred during the past two decades. Presently, performance evaluation is critical gain factors and the corporate performance evaluation is more difficult as a large number of variables (input and output) are involved in the measurement (Herczeg, 2014). Performance analysis gives opportunities to investors, particularly private equity shareholders to find the extra value for their non-financial performance (Becsky-Nagy \& Fazekas, 2014).

There are many methods in the frontier analysis to evaluate performance such as parametric and nonparametric, stochastic method (Fenyves et al., 2015). The present article introduces a non-parametric method, Data Envelopment Analysis (DEA), which is a non-parametric linear programming technique, and extends the idea of estimating efficiency by comparing each decision-making units with an efficient production frontier (Farrell, 1957). Fare et al. (1994) developed a DEA- based Malmquist productivity index (MPI). In non-parametric area, Malmquist index does not require the profit maximization or the cost minimization assumption. If the practitioner uses panel data, MPI allows the decomposition of changes in productivity (Noulas, 1997) into two components technical efficiency change and technological change. This is particularly interesting in cases of financial efficiency studies because the production frontier can shift upward or downward over time due to innovation, market structure, changes in regulatory policies, and shocks and severe financial disruptions. This explains the extensive application of total factor of productivity change in this strand of the literature (Portela \& Thanassoulis, 2010; Duygun, et al., 2016; Casu et al., 2016, Fernandes et al., 2018; Soteriou \& Zenios, 1999). This paper is structured as follows. The section 2 describes literature review. Section 3 describes methodology of DEA-MPI. The variables and data selection is presented in section 4. Result and discussion are explained in section 5. The final section offers some concluding remarks.

\section{Literature review}

Malmquist (1953) introduced the Malmquist productivity index that is a quantity index to apply in the analysis ratio of inputs and outputs. After that, Fare et al. (1994) jointed concept on the measurement of efficiency from Farrell (1957) to develop a MPI directly from input and output data by using DEA. The DEA method of measuring the technical efficiency does not allow a direct comparison of DMU's efficiency from one period to another. Therefore, this limitation does not allow the measurement of productivity growth over a period of time. The Malmquist productivity index can be defined as an index number that enables a productivity comparison of the same decision-making unit over two different periods (Zhu, 2003). Therefore, the MPI can be defined as an index number that enables a productivity comparison of the same firm over two different periods. Fare et al. (1994) considered any improvement in technical progress as evidence of innovation. Defining inputs, outputs and orientation is not a big issue in DEA (Cook et al., 2014) as many researchers preach "the input-oriented approach assuming that managers impose control over inputs variable rather than outputs variable" (Khodabakhshi et al., 2010; Tsolas \& Charles, 2015). On the other hand, others believe it is more appropriate to answer how output quantities can be proportionally expanded without changing the underlying input quantities used over different time intervals (Fethi \& Pasiouras, 2010). Although the literature was conflicting, many studies suggested that the choice of arrangement has less effect on the original finding scores. Accord-

ingly, the orientation of DEA should not be a point of disagreement among the researchers' approaches (Fernandes et al., 2018).

Many researchers found efficiency, productivity, and benchmarking of state banking institutes, commercial banking institutes or both the banking institute. For instance, Canhoto and Dermine (2003), studied the magnitude of efficiency gains of Portugese banks using DEA -MPI, found productivity improved by $59 \%$ in the banks. This improvement was contributed by technological change rather than efficiency change. Stavárek and Řepková (2012) analyzed the Czech commercial banking sector and its efficiency over the period 2001-2010, Wozniewska (2008) examined the efficiency of the Polish 
banking sector from 2000 and 2007. Moreover, Fernandes et al. (2018) applied DEA-MPI to find efficiency in peripheral European domestic banks for the year 2007-2014. The majority of the studies, although, relied on both parametric and nonparametric methods to evaluate the bank performance in terms of efficiency but they did not rank the bank.

There are few studies on banking efficiency in Malaysia but they did not discuss productivity change and efficiency together. Siew et al. (2017) studied analyses efficiency of the financial sector of Bursa Malaysia using DEA and found the most efficient company in the financial sector of Bursa Malaysia. Some studies have based on DEA in banking sector: Sufian et al. (2016) found that banks from Asian countries to be relatively more efficient rather than foreign banks, and Davies (2017) postulated that technical efficiency of Malaysian commercial banks' technical efficiency was $71.33 \%$ and also found that domestic banks had been inefficient in controlling their costs due to their size. Doaei et al. (2013) found corporate diversification highly effective in financial performance in a study on manufacturing firms listed in Bursa Malaysia.

From the brief review we understand that there had been no study on the relationship between efficiency and productivity. The above background positions this work as an important topic in the respective literature and clarifies its motivation. First, DEA efficiency scores are calculated based on a Malmquist Productivity Index (MPI) on financial company listed in Bursa Malaysia. Then, the decomposition of the productivity changes into technological efficiency changes and technical efficiency changes. The third issue is productivity change over time and relationship between efficiency and productivity. Then the method of this paper ranks the companies according to their efficiency scores.

\section{Methodology}

$D E A-M P I$

The DEA method suggested by Charnes et al. (1978) and further developed to non-constant returns (NCR) by Banker et al. (1984) explained how to design the production possibility set without guessing a production function from given a set data of input, output variables. The first stage of this study utilises a DEA approach based on the Malmquist Productivity Index (MPI) to investigate how the productivity of each company changes through time. This is accomplished by following an outputoriented DEA approach described by Färe et al. (1994). If it is not possible to gain output without increasing or decreasing input usage then a firm is deemed to be technically efficient. Specifically, efficiency is measured as the distance between the point the firm lies in the input-output space and the production frontier (technology) that envelops the data. Let $u_{n}^{t} \in R^{+}$and $v_{n}^{t} \in R^{+}$the selected input and output variables (for $N \times 1$ input and $M \times 1$ output vectors) and $\mathrm{n}$ the total number of firms, then the production $P_{n}^{t}$ in time $t$ for the firm $n$ can be expressed as:

$$
P_{n}^{t}=\left\{\left(\mathrm{u}_{n}^{t}, \mathrm{v}_{n}^{t}\right): \mathrm{v}_{n}^{t} \text { is produced by } u_{n}^{t}\right\} .
$$

The output-oriented production function under the assumption of CRS (Constant Returns to Scale) can be defined as:

$$
D_{o}^{t}\left(u_{n}^{t}, \mathrm{v}_{n}^{t}\right)=\operatorname{Min}\left\{\varphi \mid\left(u_{n}^{t}, \mathrm{v}_{n}^{t} / \varphi\right) \in P^{t}\right\}, n=1,2, \ldots i
$$

In Eq. (1), the ' 0 ' subscript denotes the output orientation of the model. The distance aims to gain in outputs, given the set of inputs but also making the outputs achievable. Particularly, it defines the technology at time $t$ of firm $n$ relative to the output technical efficiency at time $t$ (Fare et al.,1994). Here, the technical efficiency (TE) is estimated relative to the technology as $D_{o}^{t}\left(u_{n}^{t}, \mathrm{v}_{n}^{t}\right) \leq 1$. Only when the unit $n$ is on the production frontier (i.e. technically efficient), can the equation be expressed in the form as $D_{o}^{t}\left(u_{n}^{t}, \mathrm{v}_{n}^{t}\right)=1$. Alternatively, as $D_{o}^{t}\left(u_{n}^{t}, \mathrm{v}_{n}^{t}\right)<1$ means that the unit below the frontier is technically inefficient. To define the MPI, a specification of distance functions with respect to two distinct time periods is needed. The efficiency of firm $\mathrm{n}$ relative to the technology at time $t+1$ is expressed by:

$$
D_{o}^{t}\left(u_{n}^{t+1}, \mathrm{v}_{n}^{t+1}\right)=\operatorname{Min}\left\{\varphi \mid\left(u_{n}^{t+1}, \mathrm{v}_{n}^{t+1} / \varphi\right) \in P^{t}\right\}, n=1,2, \ldots i
$$


In relation to technology at time $t$, this gap calculates the maximum comparative change in outputs required to make $\left(u_{n}^{t+1}, \mathrm{v}_{n}^{t+1}\right)$ worthwhile. By using DEA linear programming method distance functions are measured. The output oriented DEA (CRS) problem is defined as below:

$$
D_{o}^{t}\left(u_{n}^{t}, \mathrm{v}_{n}^{t}\right)^{-1}=\operatorname{Max}_{n} \text { s.t. }\left\{\mid-\varphi_{n} \mathrm{v}_{n}^{t}+\mathrm{Y}_{t} \lambda \geq 0, \mathrm{u}_{n}^{t}-X_{t} \lambda \geq 0, \lambda \geq 0\right\} .
$$

Here, $X_{t}$ and $Y_{t}$ express the vector of inputs and outputs respectively and $\lambda$ represents the weight vector, which is compared with any distinct observation in order to find the distance to the efficient frontier. Caves et al. (1982) defined MPI at two consecutive time periods ( $t, s)$ as:

$$
\begin{aligned}
& \mathrm{M}^{t}\left(u_{n}^{t+1}, \mathrm{v}_{n}^{t+1}, \mathrm{u}_{n}^{t}, \mathrm{v}_{n}^{t}\right)=D_{o}^{t}\left(u_{n}^{t+1}, \mathrm{v}_{n}^{t+1}\right) / D_{o}^{t}\left(u_{n}^{t}, \mathrm{v}_{n}^{t}\right), \\
& \mathrm{M}^{t+1}\left(u_{n}^{t+1}, \mathrm{v}_{n}^{t+1}, \mathrm{u}_{n}^{t}, \mathrm{v}_{n}^{t}\right)=D_{o}^{t+1}\left(u_{n}^{t+1}, \mathrm{v}_{n}^{t+1}\right) / D_{o}^{t+1}\left(u_{n}^{t}, \mathrm{v}_{n}^{t}\right) .
\end{aligned}
$$

To avoid the use of an arbitrary benchmark, the two continuous MPIs are combined into one by estimating its geometric mean, which provides the calculation of the Total Factor Productivity Change (TFPCH):

$$
\begin{aligned}
M_{o}\left(u_{n}^{t+1}, \mathrm{v}_{n}^{t+1}, \mathrm{u}_{n}^{t}, \mathrm{v}_{n}^{t}\right)=T F P C H & =\left\{\frac{D_{o}^{t+1}\left(u_{n}^{t+1}, \mathrm{v}_{n}^{t+1}\right)}{D_{o}^{t}\left(u_{n}^{t}, \mathrm{v}_{n}^{t}\right)}\right\} \times\left\{\left(\frac{D_{o}^{t}\left(u_{n}^{t+1}, \mathrm{v}_{n}^{t+1}\right)}{D_{o}^{t+1}\left(u_{n}^{t+1}, \mathrm{v}_{n}^{t+1}\right)} \times \frac{D_{o}^{t}\left(u_{n}^{t}, \mathrm{v}_{n}^{t}\right)}{D_{o}^{t+1}\left(u_{n}^{t}, \mathrm{v}_{n}^{t}\right)}\right)^{\frac{1}{2}}\right\} \\
& =\{\mathrm{EFFCH}\} \times\{\mathrm{TECHCH}\} .
\end{aligned}
$$

When TFPCH $<1$ or $>1$, it is implied that there is a decrease or increase in productivity, while TFPCH $=1$ refers to cases where productivity is unchanged. From Eq. (6), it is also shown that TFPCH is decomposed into the Efficiency Change (EFFCH) and Technology Change (TECHCH) sub-indices as explained by Färe et al. (1994). The EFFCH ratio measures the change in technical efficiency of a DMU relative to the best practice frontier. This shows whether unit $n$ moves away from the production frontier or comes towards the production frontier between the period $t$ and $t+1$.

A firm is assumed to be technically efficient if it is impossible to increase output without altering input usage. Specifically, efficiency is measured as the distance between the point the firm lies in the inputoutput space and the production frontier (technology) that envelops the data. The Technological Change (TECHCH) component is due to the variation of the production frontier between two periods and hence, exerts improvement or deterioration of the unit's technology between the period $t$ and $t+1$. The EFFCH is further decomposed into improvements in management practices or movements toward an optimal size. As suggested by Färe et al. (1994), the first refers to a measure of Pure Technical Efficiency Change $(\mathrm{PECH})$, while the latter to a measure of Scale Efficiency Change (SECH):

$$
\begin{aligned}
& P E C H^{t, t+1}=\frac{D_{o, v}^{t+1}\left(u_{n}^{t+1}, \mathrm{v}_{n}^{t+1}\right)}{D_{o, v}^{t}\left(u_{n}^{t}, \mathrm{v}_{n}^{t}\right)}, \\
& S E C H^{\mathrm{t}, \mathrm{t}+1}=\frac{D_{o, \mathrm{c}}^{t+1}\left(u_{n}^{t+1}, \mathrm{v}_{n}^{t+1}\right)}{D_{o, c}^{t}\left(u_{n}^{t}, \mathrm{v}_{n}^{t}\right)} \times \frac{D_{o, v}^{t}\left(u_{n}^{t}, \mathrm{v}_{n}^{t}\right)}{D_{o, v}^{t+1}\left(u_{n}^{t+1}, \mathrm{v}_{n}^{t+1}\right)},
\end{aligned}
$$

\section{$\mathrm{EFFCH}=\mathrm{PECH} \times \mathrm{SECH}$.}

Here, Variable Returns to Scale (VRS) technology is used to calculate PECH, while the components of SECH are measured as the deviations between the CRS and VRS technologies. Therefore, the above subscripts "o,c" and "o,V" represents CRS and VRS technologies applied respectively for this "enhanced decomposition' (Casu et al., 2004; Berg et al., 1991).

\subsection{Data and Variables}

The data for this study is obtained from Bloomberg terminal. After excluding some companies because of lack of data, the data cover 26 financial companies of Bursa Malaysia during the period 2007-2016. Data were converted to US dollar. To construct dataset, this study uses market data for different input, 
output variables. Table 1 and Table 2 below present listed companies name and the input, output variables, respectively. For some missing data, this study have used maximum likelihood estimation method by SPSS. When determining input and output variables of financial institutes, one should first select by the nature of financial approaches. There are three approaches frequently applied in financial institutes theory of literature such as intermediation, value added and production approaches (Sealey \& Lindly, 1977). In this study, the production approach will be described because financial institutes are served as producers of services for the investor. The choice of inputs and outputs are guided by the choice made in previous studies. In this study, five outputs and three inputs are chosen. The selection of input and output variables are based on Ismail et al. (2012) and others major studies on the efficiency of financial sectors. The five input variables are market capital, total volume, dividend per share, financial leverage, price to book ratio. The three output variables are return on equity, return on assets and $\mathrm{P} / \mathrm{E}$ ratio. The software package DEAP Version 2.1 is used to measure DEA estimations (Coelli, 1996, Coelli et al., 2005).

\section{Table 1}

Company Short Name

\begin{tabular}{|c|c|}
\hline Company Name (DMUs) & Short term of companies \\
\hline MALAYAN BANKING BHD & MAY \\
\hline PUBLIC BANK BERHAD & PBK \\
\hline CIMB GROUP HOLDINGS BHD & CIMB \\
\hline HONG LEONG BANK BERHAD & HLBK \\
\hline RHB BANK BHD & RHBBANK \\
\hline HONG LEONG FINANCIAL GROUP & HLFG \\
\hline AMMB HOLDINGS BHD & AMM \\
\hline BIMB HOLDINGS BHD & BIMB \\
\hline AFFIN HOLDINGS BERHAD & AHB \\
\hline LPI CAPITAL BERHAD & LPI \\
\hline SYARIKAT TAKAFUL MALAYSIA & STMB \\
\hline ALLIANZ MALAYSIA BHD & ALLZ \\
\hline MNRB HOLDINGS BHD & MNRB \\
\hline MANULIFE HOLDINGS BHD & MHBS \\
\hline PACIFIC \& ORIENT BERHAD & $\mathrm{PO}$ \\
\hline MALAYSIA BUILDING SOCIETY & MBS \\
\hline BURSA MALAYSIA BHD & BURSA \\
\hline AEON CREDIT SERVICE M BHD & ACSM \\
\hline INSAS BHD & INS \\
\hline RCE CAPITAL BHD & RCE \\
\hline APEX EQUITY HOLDINGS BERHAD & APX \\
\hline JOHAN HOLDINGS BHD & $\mathrm{JOH}$ \\
\hline ECM LIBRA FINANCIAL GROUP BH & ECML \\
\hline HONG LEONG CAPITAL BHD & HLG \\
\hline TA ENTERPRISE BERHAD & TAE \\
\hline MAA GROUP BHD & MAA \\
\hline
\end{tabular}

Table 2

Descriptive Statistics and Variable Short Name

\begin{tabular}{|c|c|c|c|c|c|}
\hline Name of Variables & Kind of variable & Minimum & Maximum & Mean & Std. Deviation \\
\hline Total Volume (TV) & Input & 770400.0 & 3761712400 & 459870978.7 & 726230640.93 \\
\hline Dividends per share (DPS) & Input & 0.00 & 1.34 & .0481 & 0.09293 \\
\hline Market capitalization(MC) & Input & 18.09 & 26844.15 & 2868.5974 & 5378.04424 \\
\hline Price to Book Ratio(PB) & Input & 0.18 & 9.60 & 1.4813 & 1.23367 \\
\hline Financial Leverage(FL) & Input & 1.01 & 32.19 & 8.4594 & 6.39369 \\
\hline Return on Assets(ROA) & Output & -5.24 & 26.13 & 2.6349 & 3.31450 \\
\hline $\begin{array}{l}\text { Return on common Equity } \\
\text { (ROE) }\end{array}$ & Output & -27.74 & 54.75 & 12.9440 & 10.27505 \\
\hline Price earnings ratio(PE) & Output & 2.60 & 278.83 & 14.1755 & 19.37493 \\
\hline
\end{tabular}

\section{Result and Discussion}

Before discussing the DEA results, the rule of thumb (DMUs should be three times of total inputs and output variables) was applied for the selection of sample variables (inputs and outputs) that is suggested by Cooper et al. (2002). Since in this study, the total number of financial companies is twenty six that is more than the number of input and output variables (e.g. $(3 \times 5$ inputs $+3 \times 3$ outputs $)=23$ ), so the 
number of variables selection is justified since it satisfies the rule of thumb and allows the efficiencies of companies to measured.

\subsection{Technical efficiency and technical efficiency change}

This study used the Malmquist index of Productivity (MIP) to measure the productivity change of financial company listed in Bursa Malaysia for the period 2007-2016. Table 3 and Table 4 present the technical efficiency and technical efficiency change for the 26 DMUs for each year. From the dataset of Table 3 it is obvious that the average technical efficiency was 0.935 which means companies were less than 7\% inefficient to use their existing resources. On the other hand, Siew et al. (2017) found average efficiency score 0.5865 for the financial company of Malaysia. It is also seen that APX, JOH, ECML, MAA, BURSA, ACSM and LPI were fully efficient for all the time period. The results were approximately similar for most of the companies since Siew et al. (2017) also found similar results during the time period 2010-2015 where LPI, BURSA, ACSM, APX were reported to be fully efficient. The results also depict that AMM was the least efficient company as its efficiency was $79.45 \%$. Moreover, the efficiency scores of STMB, ALLZ, MNRB, and MHBS were approximately the same as it was around 0.98 .

The study would like to point out that TE change $>1$ only shows progress in technical efficiency (TE) changes. Average technical efficiency change shows that most of the companies made an increase in efficiency over the study period. From the average technical efficiency change it was seen that the highest technical efficiency change decreased for BIMB and increased for CIMB form 2007 to 2016. From the Table 4, it is seen that, all the financial companies' listed in Bursa Malaysia yearly technical efficiency declined $3 \%$ from 2007 to 2008 . Only the technical efficiency improved about $2.7 \%$ from 2008 to 2009. The average efficiency declined and improved vice versa from 2009 to 2013 for all the companies then continuously improved its efficiency from 2014 to 2015 . After that efficiency was declined by $9.8 \%$ from 2015 to 2016 . Overall, the average technical efficiency change was recorded $2.2 \%$ decline in the financial companies. Fernandes et al. (2018) found technical efficiency increased more than $1 \%$ in peripheral European domestic banks.

Table 3

Technical Efficiency

\begin{tabular}{|c|c|c|c|c|c|c|c|c|c|c|c|}
\hline Company Short Name & 2007 & 2008 & 2009 & 2010 & 2011 & 2012 & 2013 & 2014 & 2015 & 2016 & Average \\
\hline MAY & 0.854 & 1 & 0.833 & 0.826 & 0.65 & 0.832 & 0.763 & 0.865 & 0.892 & 0.658 & 0.8173 \\
\hline PBK & 0.949 & 0.995 & 1 & 0.973 & 0.83 & 0.912 & 0.816 & 0.879 & 0.908 & 0.758 & 0.902 \\
\hline CIMB & 0.919 & 0.809 & 1 & 0.87 & 0.7 & 0.867 & 0.77 & 0.894 & 0.900 & 0.616 & 0.8345 \\
\hline HLBK & 0.86 & 0.869 & 0.861 & 0.851 & 0.793 & 0.852 & 0.863 & 0.91 & 0.878 & 0.673 & 0.841 \\
\hline RHBBANK & 0.836 & 0.833 & 0.836 & 0.826 & 0.697 & 0.801 & 0.776 & 0.903 & 1 & 0.613 & 0.8121 \\
\hline HLFG & 0.866 & 0.894 & 0.866 & 1 & 0.791 & 0.891 & 0.949 & 0.932 & 0.92 & 0.620 & 0.8729 \\
\hline AMM & 0.824 & 0.793 & 0.865 & 0.823 & 0.676 & 0.821 & 0.781 & 0.863 & 0.911 & 0.588 & 0.7945 \\
\hline BIMB & 1 & 0.915 & 0.924 & 0.918 & 0.958 & 0.842 & 0.778 & 0.905 & 0.996 & 0.694 & 0.893 \\
\hline AHB & 0.814 & 0.816 & 0.86 & 0.773 & 0.716 & 0.816 & 0.875 & 0.938 & 1 & 0.661 & 0.8269 \\
\hline LPI & 1 & 1 & 1 & 1 & 1 & 1 & 1 & 1 & 1 & 1 & 1 \\
\hline STMB & 1 & 0.858 & 1 & 1 & 1 & 1 & 1 & 1 & 1 & 0.957 & 0.9815 \\
\hline ALLZ & 1 & 1 & 1 & 1 & 1 & 0.89 & 1 & 1 & 1 & 0.983 & 0.9873 \\
\hline MNRB & 1 & 1 & 1 & 1 & 0.952 & 0.864 & 1 & 1 & 1 & 1 & 0.9816 \\
\hline MHBS & 1 & 0.981 & 0.871 & 1 & 1 & 1 & 1 & 1 & 1 & 1 & 0.9852 \\
\hline PO & 1 & 1 & 1 & 1 & 1 & 0.978 & 1 & 1 & 1 & 0.695 & 0.9673 \\
\hline MBS & 0.978 & 0.969 & 0.876 & 1 & 1 & 1 & 1 & 1 & 0.998 & 0.802 & 0.9623 \\
\hline BURSA & 1 & 1 & 1 & 1 & 1 & 1 & 1 & 1 & 1 & 1 & 1 \\
\hline ACSM & 1 & 1 & 1 & 1 & 1 & 1 & 1 & 1 & 1 & 1 & 1 \\
\hline INS & 1 & 1 & 1 & 1 & 1 & 1 & 1 & 0.989 & 1 & 1 & 0.9989 \\
\hline RCE & 1 & 1 & 1 & 1 & 1 & 1 & 1 & 1 & 0.994 & 0.578 & 0.9572 \\
\hline APX & 1 & 1 & 1 & 1 & 1 & 1 & 1 & 1 & 1 & 1 & 1 \\
\hline $\mathrm{JOH}$ & 1 & 1 & 1 & 1 & 1 & 1 & 1 & 1 & 1 & 1 & 1 \\
\hline ECML & 1 & 1 & 1 & 1 & 1 & 1 & 1 & 1 & 1 & 1 & 1 \\
\hline HLG & 1 & 1 & 1 & 1 & 1 & 1 & 1 & 1 & 1 & 0.952 & 0.9952 \\
\hline TAE & 0.966 & 1 & 1 & 0.803 & 1 & 0.833 & 0.822 & 0.974 & 1 & 0.575 & 0.8973 \\
\hline MAA & 1 & 1 & 1 & 1 & 1 & 1 & 1 & 1 & 1 & 1 & 1 \\
\hline Average & 0.9563 & 0.95121 & 0.9535 & 0.9485 & 0.9139 & 0.9307 & 0.9305 & 0.9635 & 0.9768 & 0.8239 & 0.9349 \\
\hline
\end{tabular}


Table 4

Technical Efficiency Change

\begin{tabular}{|c|c|c|c|c|c|c|c|c|c|c|}
\hline DMU & $2008 / 2007$ & $2009 / 2008$ & $2010 / 2009$ & $2011 / 2010$ & $2012 / 2011$ & $2013 / 2012$ & $2014 / 2013$ & $2015 / 2015$ & $2016 / 2015$ & $2016 / 2007$ \\
\hline MAY & 2.281 & 0.517 & 0.778 & 0.869 & 0.901 & 1.393 & 1.129 & 1.144 & 0.785 & 1.002 \\
\hline PBK & 0.702 & 1.366 & 1.026 & 1.137 & 0.762 & 1.150 & 1.061 & 1.318 & 0.692 & 0.994 \\
\hline CIMB & 0.742 & 1.532 & 0.626 & 1.095 & 0.818 & 1.428 & 1.472 & 1.145 & 0.764 & 1.018 \\
\hline HLBK & 0.780 & 1.129 & 1.139 & 0.889 & 0.826 & 1.465 & 0.980 & 1.245 & 0.757 & 1.000 \\
\hline RHBBANK & 0.947 & 1.090 & 0.836 & 1.084 & 0.858 & 1.545 & 0.947 & 1.325 & 0.639 & 0.999 \\
\hline HLFG & 1.026 & 0.768 & 1.413 & 0.668 & 1.064 & 1.434 & 0.897 & 1.188 & 0.766 & 0.991 \\
\hline AMM & 0.846 & 1.304 & 0.630 & 1.116 & 0.738 & 1.571 & 1.025 & 1.523 & 0.689 & 0.996 \\
\hline BIMB & 0.705 & 0.835 & 0.978 & 0.935 & 0.583 & 1.097 & 0.886 & 1.514 & 0.612 & 0.869 \\
\hline AHB & 0.938 & 1.141 & 0.913 & 0.988 & 0.903 & 1.283 & 0.949 & 1.725 & 0.619 & 1.014 \\
\hline LPI & 1.000 & 1.000 & 1.000 & 1.000 & 1.000 & 1.000 & 0.824 & 1.213 & 1.000 & 1.000 \\
\hline STMB & 0.626 & 1.598 & 1.000 & 1.000 & 0.335 & 1.025 & 0.023 & 1.168 & 0.889 & 0.894 \\
\hline ALLZ & 1.000 & 1.000 & 1.000 & 1.000 & 0.864 & 1.157 & 1.000 & 1.000 & 0.981 & 0.998 \\
\hline MNRB & 1.000 & 1.000 & 1.000 & 0.936 & 0.875 & 1.221 & 0.687 & 1.455 & 1.000 & 1.000 \\
\hline MHBS & 0.795 & 0.815 & 1.257 & 1.258 & 1.000 & 1.000 & 1.000 & 1.000 & 1.000 & 1.003 \\
\hline $\mathrm{PO}$ & 1.000 & 1.000 & 1.000 & 1.000 & 0.785 & 1.058 & 1.205 & 1.000 & 0.662 & 0.955 \\
\hline MBS & 0.729 & 1.342 & 0.729 & 1.096 & 0.642 & 1.688 & 0.856 & 1.548 & 0.866 & 0.997 \\
\hline BURSA & 1.000 & 1.000 & 1.000 & 0.986 & 0.897 & 0.831 & 1.361 & 0.812 & 0.721 & 0.942 \\
\hline ACSM & 0.928 & 0.525 & 1.201 & 0.895 & 1.805 & 0.383 & 1.573 & 1.245 & 0.843 & 0.944 \\
\hline INS & 1.000 & 1.000 & 1.000 & 1.000 & 1.000 & 1.000 & 0.839 & 1.192 & 1.000 & 1.000 \\
\hline RCE & 1.132 & 0.755 & 1.258 & 1.186 & 1.000 & 1.000 & 1.000 & 0.959 & 0.522 & 0.951 \\
\hline APX & 1.000 & 1.000 & 1.000 & 1.000 & 1.000 & 1.000 & 1.000 & 1.000 & 1.000 & 1.000 \\
\hline $\mathrm{JOH}$ & 1.000 & 1.000 & 1.000 & 1.000 & 1.000 & 1.000 & 1.000 & 1.000 & 1.000 & 1.000 \\
\hline ECML & 1.000 & 1.000 & 1.000 & 1.000 & 1.000 & 1.000 & 1.000 & 1.000 & 1.000 & 1.000 \\
\hline HLG & 1.000 & 1.000 & 1.000 & 1.000 & 1.000 & 0.406 & 2.463 & 1.000 & 0.525 & 0.931 \\
\hline TAE & 1.048 & 1.000 & 0.616 & 1.386 & 0.714 & 0.991 & 1.076 & 1.537 & 0.538 & 0.938 \\
\hline MAA & 1.000 & 1.000 & 1.000 & 1.000 & 1.000 & 1.000 & 1.000 & 1.000 & 1.000 & 1.000 \\
\hline Average & 0.970 & 1.028 & 0.977 & 1.020 & 0.899 & 1.120 & 1.048 & 1.202 & 0.803 & 0.978 \\
\hline
\end{tabular}

\subsection{Malmquist Index Decomposition}

The DEA-MPI estimates are summarized in the Table 5. The TFPCH was decomposed into its components EFFCH, TECHCH, PECH and SECH (Fare et al., 1994). This decomposition is valuable for empirical setting, since it provides insight on the sources of overall productivity change in the financial firm. Overall, 3.13\% productivity was gained by financial companies listed in Bursa Malaysia for the period 2007-2016. Among the financial companies, the highest productivity was gained by the MHBS $(24.8 \%)$ and the lowest productivity was declined by PO (17\%). INS showed passive mode in productivity. From the decomposition of the MPI, the average TFPCH $(3.13 \%)$ was driven by $+5.38 \%$ in technological efficiency and $-2.7 \%$ in technical efficiency. This means the growth was driven mostly from the technological component rather than the technical efficiency. Fernandes et al. (2018) and Casu et al. (2004) found the same conclusion when they analyzed efficiency in peripheral European domestic banks and European banking respectively. More generally, the TFPCH of MHBS was driven by $+24.5 \%$ in technological efficiency and $+0.3 \%$ in technical efficiency. In the same way, the TFPCH of PO was declined by $-13.1 \%$ in technological efficiency and $-4.5 \%$ in technical efficiency. Now, the decomposition into PECH and SECH shows similar trends, that financial firms were decreasing their technical efficiency through the pure technical efficiency changes rather than scale ones. For example, average $2.17 \%$ declined in EFFCH is driven by the $0.3 \%$ decrease in SECH (as PECH is decreasing by $0.2 \%$ ). A large amount of improvement in technological or efficiency change can improve the total productivity. Thus, a tremendous productivity gain is mostly because of a positive shift in frontier technology and positive shift in technical efficiency. The line graph in Fig. 1 depicts the TECHCH, EFFCH and TFPCH evaluation for year between 2007 and 2016. In 2008, TECHCH and TFPCH were high but TFPCH was low. Again in 2009 the scenery was opposite of 2008. Simillar results are also seen over the study period except 2015 . From the line graph it can be inferred a tremendous productivity gain was mostly because of a positive shift in frontier technology and positive shift in technical efficiency. 
Table 5

Malmquist Index Decomposition

\begin{tabular}{|c|c|c|c|c|c|}
\hline DMU & EFFCH & TECHCH & PECH & SECH & TFPCH \\
\hline MAY & 1.002 & 1.001 & 0.972 & 1.031 & 1.002 \\
\hline PBK & 0.994 & 1.035 & 0.975 & 1.019 & 1.029 \\
\hline CIMB & 1.018 & 1.143 & 0.956 & 1.064 & 1.163 \\
\hline HLBK & 1 & 1.055 & 0.973 & 1.027 & 1.054 \\
\hline RHBBANK & 0.999 & 1.045 & 0.966 & 1.034 & 1.044 \\
\hline HLFG & 0.991 & 1.057 & 0.964 & 1.029 & 1.048 \\
\hline AMM & 0.996 & 1.113 & 0.963 & 1.034 & 1.109 \\
\hline BIMB & 0.869 & 1.082 & 0.96 & 0.905 & 0.94 \\
\hline AHB & 1.014 & 1.048 & 0.977 & 1.038 & 1.062 \\
\hline LPI & 1 & 1.036 & 1 & 1 & 1.036 \\
\hline STMB & 0.894 & 1.071 & 0.995 & 0.898 & 0.958 \\
\hline ALLZ & 0.998 & 0.956 & 0.998 & 1 & 0.954 \\
\hline MNRB & 1 & 1.064 & 1 & 1 & 1.064 \\
\hline MHBS & 1.003 & 1.245 & 1 & 1.003 & 1.248 \\
\hline $\mathrm{PO}$ & 0.955 & 0.869 & 0.96 & 0.995 & 0.83 \\
\hline MBS & 0.997 & 1.029 & 0.978 & 1.019 & 1.026 \\
\hline BURSA & 0.942 & 1.024 & 1 & 0.942 & 0.965 \\
\hline ACSM & 0.944 & 1.026 & 1 & 0.944 & 0.969 \\
\hline INS & 1 & 1 & 1 & 1 & 1 \\
\hline RCE & 0.951 & 0.968 & 0.941 & 1.011 & 0.921 \\
\hline APX & 1 & 1.133 & 1 & 1 & 1.133 \\
\hline $\mathrm{JOH}$ & 1 & 1.086 & 1 & 1 & 1.086 \\
\hline ECML & 1 & 0.968 & 1 & 1 & 0.968 \\
\hline HLG & 0.931 & 1.089 & 0.994 & 0.936 & 1.014 \\
\hline TAE & 0.938 & 1.052 & 0.944 & 0.994 & 0.987 \\
\hline MAA & 1 & 1.204 & 1 & 1 & 1.204 \\
\hline Average & 0.9783 & 1.0538 & 0.9814 & 0.997 & 1.0313 \\
\hline
\end{tabular}

Notes: The table depicts the MPI decomposition (EFFCH $=\mathrm{SECH} * \mathrm{PECH}$ and $\mathrm{TFPCH}=\mathrm{EFFCH} * \mathrm{TECHCH}$. The values $<1$ depicts decline in efficiency, while values $>1$ describes efficiency growth.

This study found that the average technical efficiency change was declined $2.17 \%$, pure technical efficiency change was declined $1.86 \%$ and scale efficiency change was declined $0.3 \%$ but productivity was increased $3.13 \%$ due to increase of technological change $5.38 \%$. These scores are in the range of what others have found (Ismail, 2005; Levine, 1998). The results indicate that the main source of inefficiency in financial sector of Bursa Malaysia was caused by technical inefficiency (failure to find the combination of inputs to produce optimal level of outputs). Based on pure technical efficiency change, the performance of the financial companies of Bursa Malaysia was relatively stable, with the score always remained close to $100 \%$ over the study period.

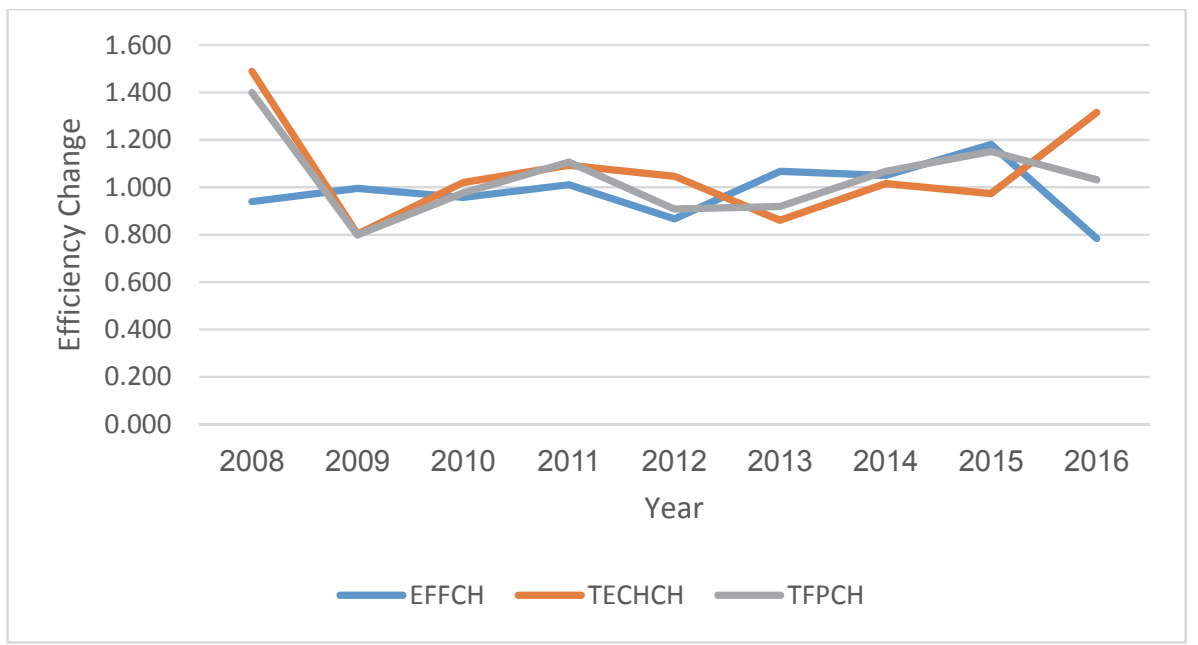

Fig. 1. Malmquist Index Summery of Annual Means 


\subsection{Efficiency scores stability over time and financial company type}

Another very important, regulatory perspective, measure relates to the efficiency scores stability over time is shown in Fig. 2. The highest number of fully efficient (Score 1) company was 17 in the years $2009,2010,2015$ and the least number of the fully efficient company was one in the year 2016. Doaei et al. (2013) found this kind of efficiency fluctuation in manufacturing firm of Bursa Malaysia. Even recognizing that some companies may go up or go down in their overall performance; except for fully efficient firm, it is unlikely that a very efficient firm in one year would become very inefficient in the following year. More generally it can be seen from Table 3 that TAE and RHBBANK were fully efficient in 2015 than in 2016 their efficiency decrease dramatically to 0.575 and 0.613 , respectively. By Bauer et al. (1998) it was reported that there was more likely an efficient firm would maintain its efficiency in next year. However, this picture was different under the efficiency approach by DEA-MPI.

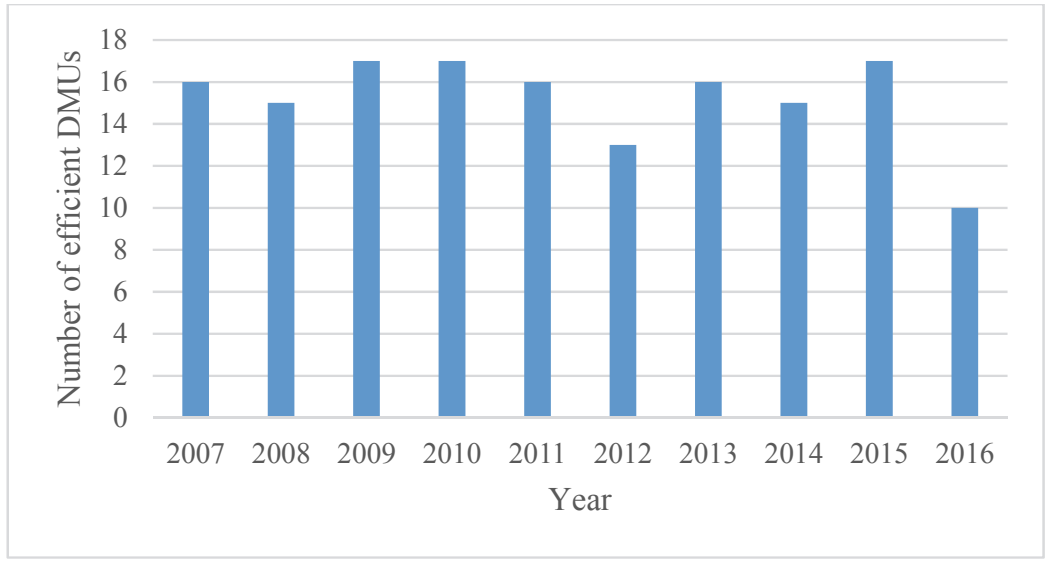

Fig. 2. Total Number of Efficient DMUs

\subsection{Efficiency, productivity change and ranking}

Fig. 3 shows the mean efficiency verses mean productivity. From the Fig. 3, it is seen that most of the companies' productivity were high, but their efficiency scores were low. Among the companies, productivity was highest in MHBS, CIMB, MAA. Almost all the companies' productivity greater than efficiency except PO, RCE, ALLZ. This kind of scenery also found by Fernandes et al. (2018) and Doaei et al. (2013) when they examined efficiency in peripheral European domestic banks and manufacturing firm of Bursa Malaysia respectively. Ranks, derived from DEA of the financial company listed in Bursa Malaysia, are shown in Table 6. Fully efficient company were LPI, BURSA, ACSM, APX, JOH, ECM, and MAA. The least efficient company was AMM but its productivity was relatively high.

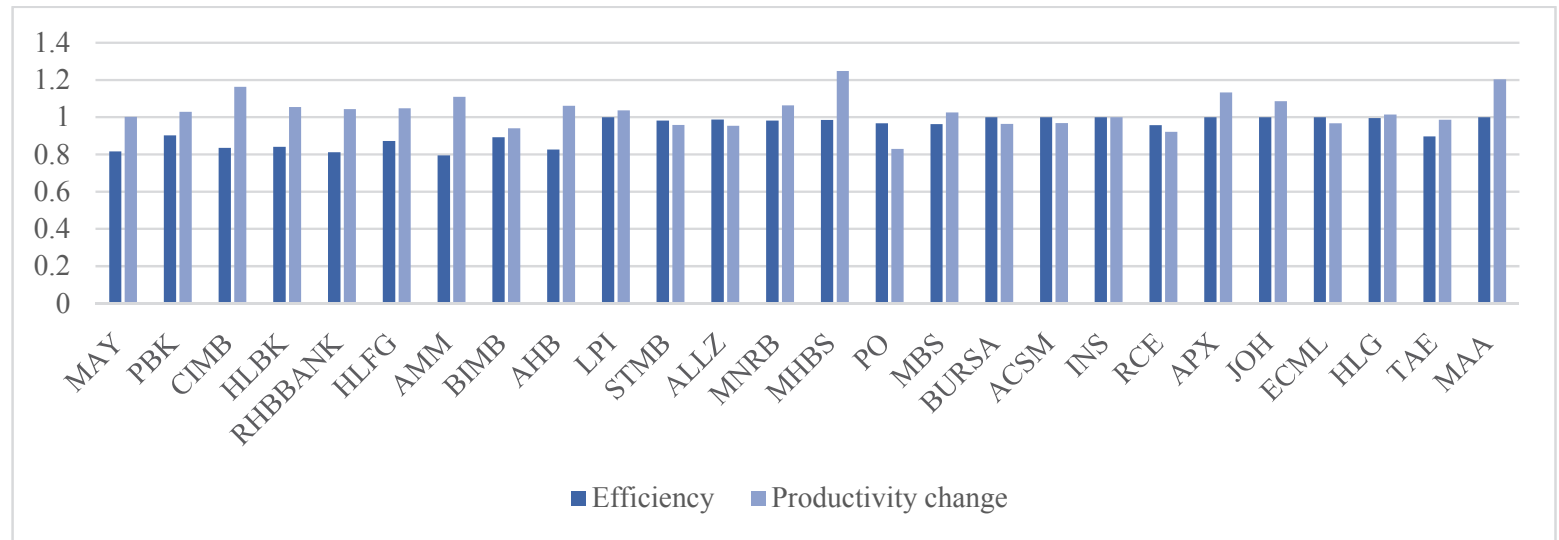

Fig. 3. Efficiency and Productivity Change 
Table 6

Ranking of the Financial Company Listed in Bursa Malaysia

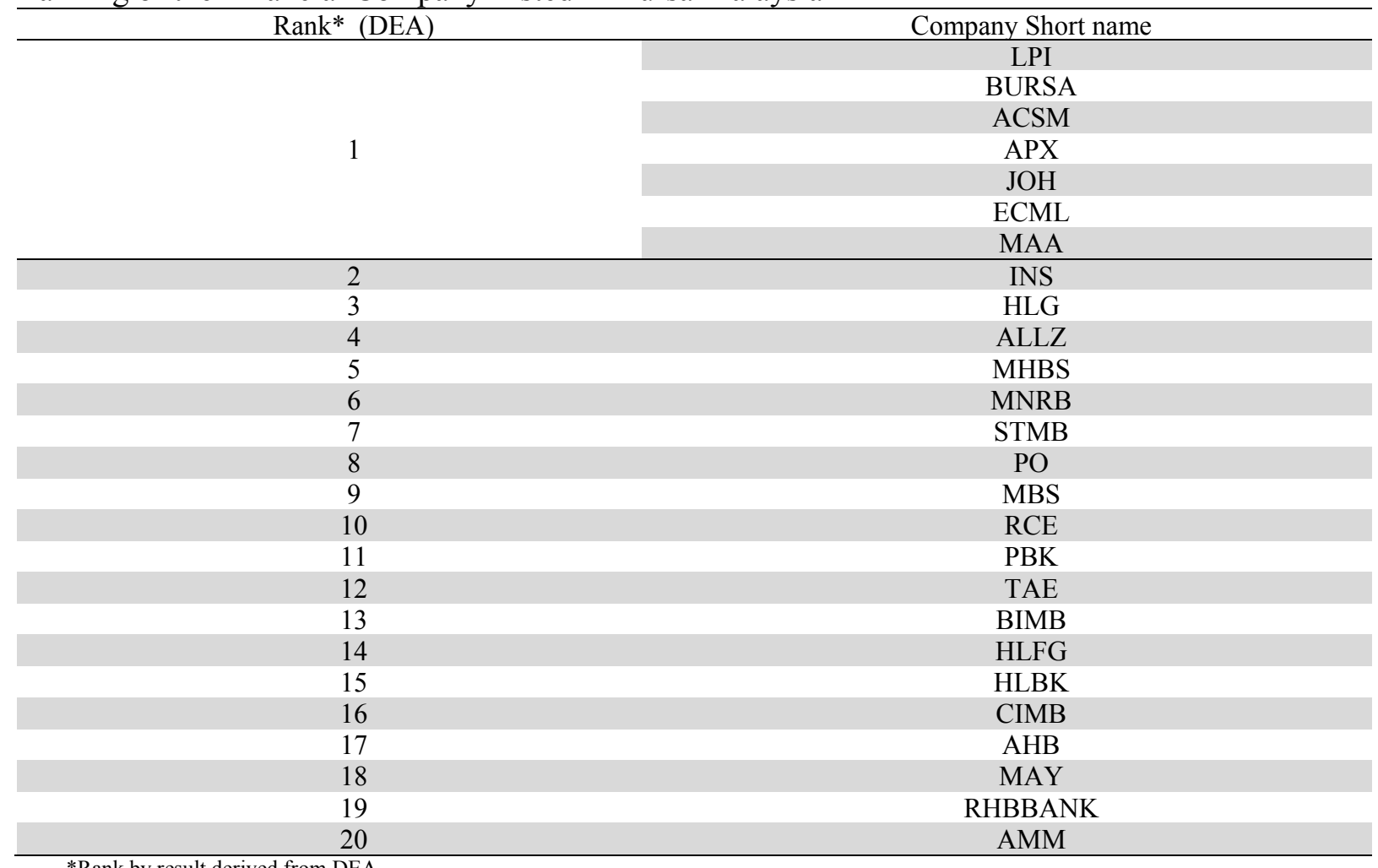

*Rank by result derived from DEA.

\section{Conclusion}

Bursa Malaysia has increased very significantly. The investors should have adequate knowledge strategy in case of stocks investment to boost their investments to at maximum level. One of the ways is to use profit optimization. The present study has provided the first attempt to identify whether or not there is a relationship between productivity and efficiency in financial companies. In the first stage of the analysis, this study used DEA-MPI to obtain efficiency and productivity of 26 listed financial companies over the period 2007-2016. The results depicted that the number of the fully efficient company was seven. Additionally, the results have indicated a tremendous productivity gain was mostly because of a positive shift in frontier technology and positive shift in technical efficiency. Based on pure technical efficiency change, the performance of the financial companies of Bursa Malaysia was relatively stable, with the score always remained close to $100 \%$ over the study period. These kinds of analysis could provide important and useful information for management decision making and regulatory investigations. Ultimately, this study observed no evidence to support our measurement most significant as the selection of variable may change the ranking.

\section{References}

Ali, M. M., Bakar, R. A., \& Ghani, E. K. (2018a). The effect of firm internal and external characteristics on risk reporting practices among Malaysian listed firms. Indonesian Journal of Sustainability Accounting and Management, 2(2), 121-135.

Ali, M., Sun, G., \& Chowdhury, M. A. A. (2018b). Dynamic interaction between macroeconomic fundamentals and stock prices in Bangladesh. Indonesian Journal of Management and Business Economics, 1(1), 66-84. 
Azizan, N. A., \& Sorooshian, S. (2014). Stock market performance and modern portfolio theory: Case on Malaysian stock market and Asian indices. WSEAS Transactions on Business and Economics, 11(303), 2224-2899.

Banker, R.D., Charnes, A., \& Cooper, W.W. (1984). Some models for estimating technical and scale inefficiencies in data envelopment analysis. Management Science, 30(9), 1078-1092.

Bauer, P. W., Berger, A. N., Ferrier, G. D., \& Humphrey, D. B. (1998). Consistency conditions for regulatory analysis of financial institutions: A comparison of frontier efficiency methods. Journal of Economics and Business, 50(2), 85-114.

Becsky-Nagy, P., Fazekas, B. (2014). Returns of private equity: comparative analyses of the returns of venture capital and buyout funds in Europe and in the US Annals of the University of Oradea. Economic Science, 2(2), 820-827.

Berg, S. A., Forsund, F. R., \& Jansen, E. S. (1991). Technical efficiency of Norwegian banks: The nonparametric approach to efficiency measurement. Journal of Productivity Analysis, 2(2), 127-142.

Canhoto, A. and Dermine J. (2003). A note on banking efficiency in Portugal, New vs. Old banks. Journal of Banking and Finance, 27, 2087-2098.

Casu, B., Ferrari, A., Girardone, C., \& Wilson, J. O. (2016). Integration, productivity and technological spillovers: Evidence for Eurozone banking industries. European Journal of Operational Research, 255(3), 971-983.

Casu, B., Girardone, C., \& Molyneux, P. (2004). Productivity change in European banking: A comparison of parametric and non-parametric approaches. Journal of Banking \& Finance, 28(10), 25212540.

Caves, D. W., Christensen, L. R., \& Diewert, W. E. (1982). The economic theory of index numbers and the measurement of input, output, and productivity. Econometrical: Journal of the Econometric Society, 50(6), 1393-1414.

Charnes, A., Cooper, W. W., Rousseau, J., \& Semple, J. (1987). Data Envelopment Analysis and Axiomatic Notions of Efficiency and Reference Sets. Research Report CCS 558. Centre for Cybernetic Studies. The University of Texas. Austin.

Coelli, T.J. (1996). A Guide to DEAP Version 2.1 A Data Envelopment Analysis (Computer) Program. CEPA Working Paper 96/08. University of New England. Armidale.

Coelli, T. J. , Prasada Rao, D. S. , O’Donnell, C. J. , \& Battese, G. E. (2005). An introduction to efficiency and productivity analysis (2nd Ed.). Springer.

Cook, W. D., Tone, K., \& Zhu, J. (2014). Data envelopment analysis: Prior to choosing a model. Omega, 44, 1-4.

Cooper, W. W., Seiford, L. M., \& Tone, K. (2002). Data envelopment analysis, a comprehensive text with models, applications, references and DEA-solver software. Boston: Kluwer Academic Publishers.

Doaei, M., \& Shavazipour, B. (2013). Corporate diversification and efficiency of manufacturing firms listed in Bursa Malaysia. International Journal of Business and Development Studies, 8(1), 77-96.

Duygun, M., Sena, V., \& Shaban, M. (2016). Trademarking activities and total factor productivity: Some evidence for British commercial banks using a metafrontier approach. Journal of Banking \& Finance, 72, S70-S80.

Färe, R., Grosskopf, S., Norris, M., \& Zhang, Z. (1994). Productivity growth, technical progress, and efficiency change in industrialized countries. The American Economic Review, 84(1), 66-83.

Fenyves, V., Tarnóczi, T., \& Zsidó, K. (2015). Financial performance evaluation of agricultural enterprises with DEA method. Procedia Economics and Finance, 32(15), 423-431.

Fernandes, F. D. S., Stasinakis, C., \& Bardarova, V. (2018). Two-stage DEA-Truncated Regression: Application in banking efficiency and financial development. Expert Systems with Applications, 96, 284-301.

Fethi, M. D., \& Pasiouras, F. (2010). Assessing bank efficiency and performance with operational research and artificial intelligence techniques: A survey. European Journal of Operational Research, 204(2), 189-198. 
Herczeg, A. (2014). Financing Aspects of the Hungarian general manufacturers in 2010-2012: The Annals of the University of Oradea (pp.905-91). Economic Sciences, Tom XXIII -2014 .

Ismail, M. K. A., Rahman, N. M. N. A., Salamudin, N., \& Kamaruddin, B. H. (2012, May). DEA portfolio selection in Malaysian stock market. In Innovation Management and Technology Research (ICIMTR), 2012 International Conference on (pp. 739-743). IEEE.

Ismail, M., (2005). A study of efficiency and competitive Behaviour of commercial Banks in Malaysia (Doctoral thesis). Retrieved from UMI Dissertation Publishing, UMI Number U584012.

John, E. I. (2018). Macroeconomic determinants of stock market performance in Nigeria: An econometric approach. Indonesian Journal of Applied Business and Economic Research, 1(1), 47-58.

Khodabakhshi, M., Asgharian, M., \& Gregoriou, G. N. (2010). An input-oriented super-efficiency measure in stochastic data envelopment analysis: Evaluating chief executive officers of US public banks and thrifts. Expert Systems with Applications, 37(3), 2092-2097.

Levine, R. (1998). The legal environment, banks, and long run economic growth. Journal of Money, Credit and Banking, 30(3), 596-613.

Malmquist, S. (1953). Index numbers and indifferent surfaces. Trabajos de Estadica, 4, 209-242.

Noulas, A. G. (1997). Productivity growth in the Hellenic banking industry: State versus private banks. Applied Financial Economics, 7(3), 223-228.

Ong, T. S., \& Ng, P. S. (2018). The effects of share repurchase announcements on returns in the Malaysia stock market. Indonesian Journal of Business Finance and Accounting, 1(1), 1-19.

Orbán, Mrs., \& Tamás Dékán, I. (2013): Reporting companies’ performance. International Financial Reporting Standards (IFRS), 7(5), 107-112.

Portela, M. C., \& Thanassoulis, E. (2010). Malmquist-type indices in the presence of negative data: An application to bank branches. Journal of Banking \& Finance, 34(7), 1472-1483.

Rashid, A., \& Mehmood, A. (2018). Downside risk analysis of returns of financial institutions in Pakistan. Indonesian Journal of Management and Business Economics, 1(1), 1-18.

Rossi, M., \& Gunardi, A. (2018). Efficient market hypothesis and stock market anomalies: Empirical evidence in four European countries. Journal of Applied Business Research, 34(1), 183-192.

Sealey, C.W.J., \& Lindley, J.T. (1977). Inputs, outputs, and a theory of production and cost at semiparametric methodology. Managerial Finance, 35(3), 260-275.

Siew, L. W., Fai, L. K., \& Hoe, L. W. (2017). An empirical investigation on the efficiency of financial companies in Malaysia with data envelopment analysis model. American Journal of Information Science and Computer Engineering, 3(3), 32-38.

Soteriou, A. C., \& Zenios, S. A. (1999). Using data envelopment analysis for costing bank products. European Journal of Operational Research, 114(2), 234-248.

Stavárek, D., \& Řepková, I. (2013). Efficiency in the Czech banking industry: A non-parametric approach. Acta Universitatis Agriculturae et Silviculturae Mendelianae Brunensis, 60(2), 357-366.

Sufian, F., Kamarudin, F., \& Nassir, A. M. (2016). Determinants of efficiency in the Malaysian banking sector: Does bank origins matter? Intellectual Economics, 10(1), 38-54.

Tsolas, I. E., \& Charles, V. (2015). Incorporating risk into bank efficiency: A satisficing DEA approach to assess the Greek banking crisis. Expert Systems with Applications, 42(7), 3491-3500.

Vardar, G. (2013). Efficiency and Stock Performance of Banks in Transition Countries: Is There A Relationship? International Journal of Economics and Financial Issues, 3(2), 355-369.

Wozniewska, G. (2008). Methods of measuring the efficiency of commercial banks: an example of Polish banks, Ekonomika, 84, 81-91.

Zhu, J. (2003). Quantitative models for performance evaluation and benchmarking: Data envelopment analysis with spreadsheets. Kluwer Academic Publishers, Boston.

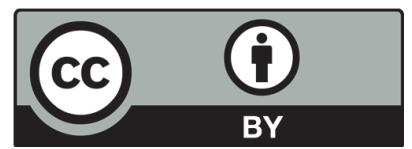

(C) 2019 by the authors; licensee Growing Science, Canada. This is an open access article distributed under the terms and conditions of the Creative Commons Attribution (CC-BY) license (http://creativecommons.org/licenses/by/4.0/). 